\title{
The Effects of Aerobic Exercise Training on Basal Metabolism and Physical Fitness in Sedentary Women
}

\author{
Fatma Kizilay $^{1}$, Cengiz Arslan², Fatma İ. Kerkez ${ }^{3}$, Aysegul Beykumul1, Egemen Kizilay ${ }^{4}$ \\ ${ }^{1}$ PMR Department, Turgut Ozal Medical Center, Inonu University, Malatya, Turkey \\ ${ }^{2}$ Faculty of Sports Science, Firat University, Elazıg, Turkey \\ ${ }^{3}$ School of Physical Education and Sports, Mugla Sıtkı Kocman University, Mugla, Turkey \\ ${ }^{4}$ PMR Clinic, Malatya State Hospital, Malatya, Turkey \\ Email: "fatmakizilay@hotmail.com.tr
}

Received 24 November 2015; accepted 26 January 2016; published 29 January 2016

Copyright (C) 2016 by authors and Scientific Research Publishing Inc.

This work is licensed under the Creative Commons Attribution International License (CC BY).

http://creativecommons.org/licenses/by/4.0/

(c) ()

\begin{abstract}
Objective: Aerobic exercises are the basic activity on fight against obesity. And obesity is related with metabolic rate. So our study is aimed to investigate the effects of 8 weeks aerobic exercise on basal metabolic rate and physical parameters. Methods: Sedentary women between the ages of 35 - 45 (n $=40)$ were randomized into control group (CG) $(n=20)$ and exercise group (EG) (n = 20). EG underwent 8 weeks of aerobic-run-walk exercise training: 3 days a week, 1 hour sessions. The CG was not trained. Basal metabolic rate (BMR), body mass index (BMI), waist-hip ratio (WHR), body fat percentage (BFP), body fat mass (FM) and lean body mass (LBM) were measured for all of the subjects before and after the training program. Results: Mean BMR decreased from $1386 \pm 213.6$ kcal to $1327 \pm 253.7$ in CG, and raised from $1308 \pm 201.8$ to $1409 \pm 218.3 \mathrm{kcal}$ in EG. While BMI raised from $31.39 \pm 6.15 \mathrm{~kg} / \mathrm{m}^{2}$ to $31.51 \pm 6.09 \mathrm{~kg} / \mathrm{m}^{2}$ in $\mathrm{CG}$, it decreased from $29.62 \pm 3.78 \mathrm{~kg} / \mathrm{m}^{2}$ to $28.47 \pm 3.74 \mathrm{~kg} / \mathrm{m}^{2}$ in EG. There was also statistically significant difference in parameters of WHR, BFP, FM and LBM in favour of EG $(p<0.05)$. Conclusion: After 8 weeks aerobic exercise training program, there was a statistically significant difference in favour of EG in BMR, BMI, BFP, FM, LBM, WHR and weight parameters.
\end{abstract}

\section{Keywords}

Sedentary, Aerobic, Basal Metabolism, Physical Fitness

\footnotetext{
${ }^{*}$ Corresponding author.
}

How to cite this paper: Kizilay, F., Arslan, C., Kerkez, F.I., Beykumul, A. and Kizilay, E. (2016) The Effects of Aerobic Exercise Training on Basal Metabolism and Physical Fitness in Sedentary Women. Health, 8, 173-180. 


\section{Introduction}

The importance of exercise in daily life has increased due to developing technology and studies focusing on this subject. Obesity which is closely associated with energy metabolism is a very common health problem in nearly all societies and becoming a global epidemic [1]. Obesity is common in the United States and is a major public health problem because of its association with considerable morbidity, including hypertension, diabetes mellitus, and coronary artery disease [2] [3]. Sedentary lifestyle is a major factor causing obesity. The appearance of increase in the risk of hypertension, metabolic syndrome and diabetes in adults if sedentary lifestyle becomes more widespread in the future, emphasizes the need of focus to health and coronary heart disease on society in terms of protection [4]. Lately though, as a result of the emphasis on this requirement, a partly awareness of sport has begun to occur. Due to this awakening, new sports options have been consisting. For example, the number of people who have been deailng with Pilates in the United States exceeded 5 million at this point [5]. Exercises which everyone will find easier and to do by one's own such as cycling, walking and running, maintain their own importance and popularity from the past to the present. Latey (2001) pointed out that this increase in people's demand on doing sports occured due to protection from injuries and wellness status [6]. Fundamental elements of being healthy are balanced body composition, physical fitness and to be able to keep it well [7]. Various techniques like BMI, skinfold, circumference measurements and bioelectrical impedance analysis (BIA) are used to determine physical fitness [8].

Metabolism and its speed are also effective factors on physical well-being. Anabolic and catabolic processes in the organism are always in equilibrium. Almost all the body's cells are renewed permanently, they are synthesized apart again. Also, metabolic activity can be described as generating new molecules from one to another [8]. Return of surplus proteins and carbonhydrates to fat in the organism is basically related with this metabolism [9] [10]. BMR, which is an important parameter of energy metabolism, is the lowest amount of energy, necessary for the vital functions of the person [11]. Basal metabolism comprises $60 \%$ to $75 \%$ of the daily energy expenditure [12]. Activities of the brain, heart, kidneys and other organs constitute a significant portion of BMR, the main cause of differences between people are amount of skeletal muscles, the fat mass and body size [13]. Therefore metabolic rate is lower in women compared with men [2]. In people whose LBM is more, their BMR is higher too. Between the ages of $20-40$, for each $\mathrm{m}^{2}$ of body surface area men spend $38 \mathrm{kcal}$, while women spend $35 \mathrm{kcal}$ average [14] [15]. Metabolic activity of adipose tissue, and therefore energy consumption is lower than in the muscle tissue. The changes of body combine which occur in adulthood, so agerelated increase in fat mass and decrease in lean mass explains the decrement of $2 \%$ - 3\% of BMR in adult men and women decennially [12].

The effects of exercise on basal metabolism is the subject of researches for many years. Studies obtained different results are available on this topic [16]-[19]. There is no consensus regarding the long-term effects of regularly done physical activity on basal metabolism. This disagreement raises the necessity of new researches. Further studies are needed to define the role of energy metabolism on determining exercise approaches to treat obesity. Therefore the aim of this study is to examine the effect of 8-week aerobic exercise on basal metabolic rate and physical parameters in premenopausal sedentary women.

\section{Materials and Methods}

\subsection{Participants}

40 healthy female premenopausal volunteers between the ages of 35 - 45 with sedentary life style participated in the study. Volunteers were randomized into two groups; CG with $40.30 \pm 4.47$ mean age $(n=20)$ and EG with $41.05 \pm 3.26$ mean age $(E G)(n=20)$.

Individuals with a history of chronic disease, surgery, smoking, having or had on a diet or exercise program for last one year, or in a pregnancy or breastfeeding period were excluded. Individuals were selected by criteria on to be sedentary women in premenopausal period and between the ages of 35 - 45.

Before starting the research participants were informed about the content of the study, its purpose, application and the potential risks. Voluntary consent forms were distributed and were signed to all participants. Consent was obtained from "Malatya Clinical Research Ethics Committee" for this research (decision no: 2011-32). Subsequently, CG had not undergone exercise program; EG did aerobic-run-walk exercise 1 hour a day, 3 days a week for 8 weeks. BMR, BMI, WHR, BFP, FM and LBM were measured for all of the subjects before and after the training program. 


\subsection{Study Design}

At the weeks before the beginning and immediately after the 8 weeks of aerobic exercise, volunteers were invited to the laboratory for measurements. BMR measurement which was to be done on resting condition and after 12 hours of fasting, performed between 8:00 to 10:00 am. According to the admission criteria, from the day of measurements subjects were required to avoid from smoking environment.

Temperature of room which measurements will be performed in, fixed with air conditioning to $22^{\circ} \mathrm{C}$. Also necessary isolation provided for not to change of humidity, light and sound. Light dose was isolated to be slightly dark and quiet room. All measurements were performed by an experienced person using the same equipment for each subject.

The measurements were made in the following order:

- Height and weight values required for the BMR measurement was measured and recorded.

- For BMR measurement each participant was allowed to rest on supine position 30 minutes (min.) prior of measurement.

- BMR measurements performed for $30 \mathrm{~min}$. after resting period.

- BMR measurement ending subjects were taken into BIA measurements.

- Subsequently circumference measurements were performed.

\subsection{Experimental Protocol}

\subsubsection{Height and Weight Measurement}

Height measurement is powered by a Soehnle brand gauge working with ultrasound method [20].

Tanita brand bioelectrical impedance analyzer "Tanita Body Composition Analyser BC-418" was used for weight measurement. Weight of subject's clothes were allowed to be deducted from the weight of subject. After all reading from the device's LCD screen values have been saved [20].

\subsubsection{BMR Measurement}

Fit Mate ${ }^{\circledR}$ BMR measurement device of Cosmed firm was used. The subjects was measured after 30 min. of rest in the supine position. Sensor mask of device was used separately for each participant. Subjects were measured while normal breathing for $30 \mathrm{~min}$. Subjects warned about not to move during the measurement. At the end of measurement automatic output was received and the BMR value (kcal) recorded [21].

\subsubsection{Bioelectrical Impedance Analysis (BIA)}

“Tanita Body Composition Analyzer BC-418” was used for BIA analysis. Height (cm), age (years) and subject's clothes weigt (kg) values were entered to divice. With this device LBM, BFP, FM parameters were calculated and automatic output received. BMI value was calculated using the formula weight $(\mathrm{kg}) / \mathrm{height}(\mathrm{m})^{2}$ [22].

\subsubsection{Circumference Measurements}

Circumference measurements were performed using standard tape measure (Gullick strip). For determining of waist-to-hip ratio, 2 region of body measured (waist, hips). The measurement region of subjects was allowed to be naked. Circumference measurements were repeated three times to each point and taking the mean value of these three measurements was recorded.

Waist: waist measured at the narrowest area parallel to the ground during normal breathing. Hips: maximum protrusion of the buttocks muscle (gluteus maximus) were measured in parallel position over the place [8]. WHR value obtained by dividing waist circumference to hip circumference (WHR = waist circumference/hip circumference) [23].

\subsection{Weeks Exercise Protocol}

Run-walk exercises are made in the 1700-meters jogging track located on the Inonu University campus. Heart rate was controlled with portable polar device during exercise. Exercise intensity was determined with Karvonen Method [24] and the number of heart beats were calculated for each subject separately [11]. Exercise group did run-walk exercises in the intensity of $60 \%$ target heart rate 1 hour a day, 3 days a week for 8 weeks. Table 1 shows the training program. 
Table 1. Applied training program.

\begin{tabular}{|c|c|c|c|c|}
\hline Weeks & Exercise & $\begin{array}{l}\text { Exercise Period } \\
\text { (min) }\end{array}$ & $\begin{array}{c}\text { Distance } \\
\text { (km) }\end{array}$ & $\begin{array}{l}\text { Frequency } \\
\text { (day/week) }\end{array}$ \\
\hline & Warm-up & 10 & & \\
\hline \multirow[t]{2}{*}{$1-2$} & Training Period & 45 & 4 & 3 \\
\hline & Cool-Down & 5 & & \\
\hline $3-4$ & Same with first week & 60 & 5 & 3 \\
\hline $5-6$ & Same with first week & 60 & 6 & 3 \\
\hline $7-8$ & Same with firts week & 60 & 6 & 3 \\
\hline
\end{tabular}

Warm-up Period (10 min.):

- Light tempo 5 min. jog, direction-changing walks,

- Warm-up and stretching exercises for the muscle groups to be used in the exercise [25].

Training Period (45 min):

- Run-walk exercises at Inonu University jogging track with $60 \%$ of maximum heart rate of subjects determined with Karvonen method [24].

Cool-down Period (5 min):

- Light Tempo jogging,

- Minimal Stretching [25].

\subsection{Statistical Analysis}

Mann-Whitney U test was used to determine whether there are differences in age, height and weight parameters between exercise and control groups in this study. Normal distribution of data was examined by the Kolmogorov-Smirnov test. Two-way analysis of variance (ANOVA) was used for comparison of pre-test - post test results. All statistical analyzes were performed using SPSS program and the significance level was set at 0.05 .

\section{Results}

After randomisation of 40 healthy female volunteers into two groups; control group $(\mathrm{n}=20)$ and exercise group ( $n=20)$ Mann-Whitney U test was used for comparison of age, height, weight, WHR, BMI, BFP, FM, LBM and BMR between two groups before the intervention. There was no statistically significant difference between CG and EG (p > 0.05).

Table 2. Descriptive statistics of circumference measurements.

\begin{tabular}{|c|c|c|c|c|c|c|c|c|c|c|}
\hline \multirow{3}{*}{ VARIABLES } & \multicolumn{4}{|c|}{$C G(n=20)$} & \multicolumn{4}{|c|}{$E G(n=20)$} & \multirow{3}{*}{$\boldsymbol{F}$} & \multirow{3}{*}{$\mathbf{p}$} \\
\hline & \multicolumn{2}{|c|}{ Pre test } & \multicolumn{2}{|c|}{ Post test } & \multicolumn{2}{|c|}{ Pre test } & \multicolumn{2}{|c|}{ Post test } & & \\
\hline & $\bar{X}$ & $S D$ & $\bar{X}$ & $S D$ & $\bar{X}$ & $S D$ & $\bar{X}$ & $S D$ & & \\
\hline Waist (cm) & 102.72 & 12.15 & 103.78 & 12.97 & 98.65 & 9.58 & 93.27 & 8.07 & 54.966 & $0.000^{*}$ \\
\hline Hip (cm) & 115.47 & 10.45 & 116.42 & 11.02 & 111.17 & 7.41 & 107.65 & 7.00 & 83.452 & $0.000^{*}$ \\
\hline WHR (\%) & 0.88 & 0.04 & 0.89 & 0.05 & 0.88 & 0.05 & 0.86 & 0.06 & 6.464 & $0.015^{*}$ \\
\hline
\end{tabular}

*There was a statistically significant difference $(\mathrm{p}<0.05)$.

As shown in Table 2 waist circumference values remained unchanged after the final test in the control group, a statistically significant reduction is detected in the exercise group ( $<<0.05$ ). While hip circumference increased in the control group, decrease was observed in the exercise group and the difference was statistically significant $(\mathrm{p}<0.05)$. Waist-hip ratio remained unchanged in the control group, decreased in the exercise group and according to the latest test scores this difference was found statistically significant $(\mathrm{p}<0.05)$. 
Table 3. Change of the physical fitness parameters.

\begin{tabular}{|c|c|c|c|c|c|c|c|c|c|c|}
\hline \multirow{3}{*}{ VARIABLES } & \multicolumn{4}{|c|}{$C G(n=20)$} & \multicolumn{4}{|c|}{$E G(n=20)$} & \multirow{3}{*}{$\boldsymbol{F}$} & \multirow{3}{*}{$\mathbf{p}$} \\
\hline & \multicolumn{2}{|c|}{ Pre test } & \multicolumn{2}{|c|}{ Post test } & \multicolumn{2}{|c|}{ Pre test } & \multicolumn{2}{|c|}{ Post test } & & \\
\hline & $\bar{X}$ & $S D$ & $\bar{X}$ & $S D$ & $\bar{X}$ & $S D$ & $\bar{X}$ & $S D$ & & \\
\hline Weight (kg) & 81.17 & 15.15 & 81.43 & 15.15 & 74.81 & 11.68 & 72.03 & 11.68 & 69.372 & $0.000^{*}$ \\
\hline BMI (kg/m²) & 31.39 & 6.15 & 31.51 & 6.09 & 29.62 & 3.78 & 28.47 & 3.74 & 7.957 & $0.000^{*}$ \\
\hline BFP (\%) & 36.64 & 6.28 & 35.53 & 6.32 & 37.10 & 4.47 & 34.59 & 4.47 & 12.340 & $0.001^{*}$ \\
\hline FM (kg) & 30.54 & 10.52 & 29.06 & 9.64 & 28.12 & 7.46 & 25.47 & 7.46 & 7.037 & 0.012 \\
\hline LBM (kg) & 46.63 & 4.68 & 46.69 & 5.03 & 50.62 & 5.41 & 51.55 & 5.95 & 6.000 & $0.019^{*}$ \\
\hline
\end{tabular}

*There was a statistically significant difference $(\mathrm{p}<0.05)$.

While BMI raised from $31.39 \pm 6.15 \mathrm{~kg} / \mathrm{m}^{2}$ to $31.51 \pm 6: 09 \mathrm{~kg} / \mathrm{m}^{2}(0.38 \%)$ in CG, it was decreased from $29.62 \pm 3.78 \mathrm{~kg} / \mathrm{m}^{2}$ to $28.47 \pm 3.74 \mathrm{~kg} / \mathrm{m}^{2}$ (3.11\%) in EG. While LBM was raised from $46.63 \pm 4.68 \mathrm{~kg}$ to 46.69 \pm 5.03 in CG, it was increased from $50.62 \pm 5.41 \mathrm{~kg}$ to $51.55 \pm 5.95 \mathrm{~kg}$ in the exercise group. BFP was decreased $3.02 \%$ in the control group, $6.76 \%$ in the exercise group. FM was decreased $4.84 \%$ in the control group, $9.42 \%$ in the exercise group and there was a statistically significant difference between groups according to the last test results $(\mathrm{p}<0.05)$.

Table 4. Change of BMR values.

\begin{tabular}{|c|c|c|c|c|c|c|c|c|c|c|}
\hline \multirow{3}{*}{ VARIABLE } & \multicolumn{4}{|c|}{$C G(n=20)$} & \multicolumn{4}{|c|}{$E G(n=20)$} & \multirow{3}{*}{$F$} & \multirow{3}{*}{$\mathbf{p}$} \\
\hline & \multicolumn{2}{|c|}{ Pre test } & \multicolumn{2}{|c|}{ Post test } & \multicolumn{2}{|c|}{ Pre test } & \multicolumn{2}{|c|}{ Post test } & & \\
\hline & $\bar{X}$ & $S D$ & $\bar{X}$ & $S D$ & $\bar{X}$ & $S D$ & $\bar{X}$ & $S D$ & & \\
\hline BMR (kcal) & 1386 & 213.6 & 1327 & 253.7 & 1308 & 201.8 & 1409 & 218.3 & 5.41 & $0.025^{*}$ \\
\hline
\end{tabular}

*There was a statistically significant difference $(\mathrm{p}<0.05)$.

BMR value remained unchanged in the control group, increased in the exercise group and according to the test scores this difference was found statistically significant $(p<0.05)$. Figure 1 presents the change of BMR value in CG and EG.

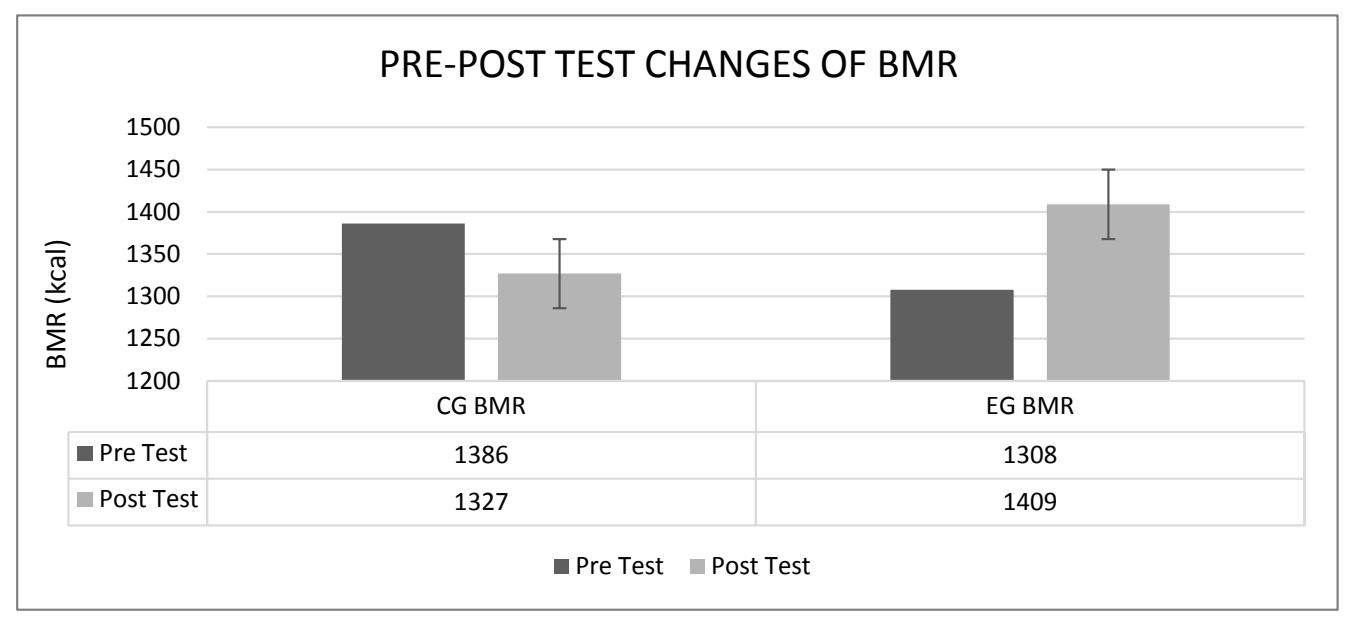

Figure 1. Change of BMR in EG and CG.

\section{Discussion}

There are several studies about the aerobic exercises and their effects. Our study has been focused on aerobic 
exercise too and carried out to investigate the effects of 8 weeks of aerobic-run-walk exercise training on BMR and physical fitness parameters in sedentary women between the ages of 35 - 45. After 8 weeks aerobic run-walk exercise program there was a statistically significant difference between CG and EG in the parameters of BMR, BMI, BFP, FM, LBM, WHR and weight $(\mathrm{p}<0.05)$ (Table 3). In this respect, Amano et al. have reported that obese men and women who underwent aerobic exercise training for 30 minutes, three times a week, over 12 weeks had significant reduction in body weight, BMI, BFP, FM and LBM in their study [1]. Again like that as, William et al. were randomly assigned sedentary women to one of three groups that either 1) performed 25 min. of step aerobic exercise only; 2) performed a combination of 25 min. of step aerobic exercise and a multiple-set upper and lower body resistance exercise program; 3) performed 40 min of step aerobic exercise only to investigate the effects of different exercise groups to physical and physiologic performance parameters and observed significant reduction in BFP $(5 \%-6 \%)$ in all training groups after training [26].

In a randomized controlled trial, 60 patients were randomly divided into 3 groups: control group, group with aerobic exercise, and group with resistance exercise in a study. After 12 weeks of exercise, statistically significant decreases in BMI and FM were noted in groups with aerobic and resistance exercises [27]. Struggling with obesity gained further importance nowadays and thus easily accessible and inexpensive methods like exercise and results of the studies about the exercise gained importance [17] [27]-[29].

Our study showed that positive effects can be achieved with only an 8-week aerobic exercise program. The results of the study are valuable in the fight against obesity. The role of aerobic exercise in increasing basal metabolism is trying to be identified with studies. At this point, the results obtained from our study appears to provide a significant contribution.

In a randomized controlled intervention trial, Geliebter et al. assigned sixty-five (25 men and 40 women) moderately obese subjects (aged 19 - 48 y) to one of three groups: diet plus strength training, diet plus aerobic training, or diet only. Statistically significant differences were found in BMR in all of the groups [30]. Douglas and Poehlman investigated 82 young women who separated into three groups: sedentary $(n=48)$, aerobically trained $(\mathrm{n}=21)$, and resistance trained $(\mathrm{n}=13)$; only aerobic exercise group had statistically significant difference in BMR than the other two groups [31]. These studies show aerobic exercises are more effective on the basal metabolism when compared to resistance exercise but our study provides answers to the questions of how often, with how much load and how long these exercises should be done. In our study, BMR was found to decrease from $1386 \pm 213.6 \mathrm{kcal}$ to $1327 \pm 253.7$ in CG, raised from $1308 \pm 201.8$ to $1409 \pm 218.3 \mathrm{kcal}$ in EG and there was a statistically significant difference between EG and CG $(\mathrm{p}<0.05)$ (Table 4). After 8 weeks of aerobic-run-walk exercise training: 3 days a week, 1 hour sessions there was a statistically significant BMR difference in our study.

Studies concerning how metabolic activity is influenced by exercise in obese, gain more importance day by day. In our study, 40 subjects with the mean BMI 31.45 and defined as obese according to obesity index by the WHO were evaluated and effects of the exercise on obesity parameters were investigated [22]. This study's limitation was to be worked with a small number of objects. So there is need of new studies including large number of subjects to define the role of aerobic exercise on basal metabolism and physical fitness.

\section{Conclusion}

BMR value increased significantly in the exercise group and patients with "obesity" status got in the "overweight” category. Consequently, 8 weeks of aerobic exercise is effective in increasing basal metabolic rate and normalising physical fitness in sedentary women due to our study results.

\section{Note}

This study was presented as a poster presentation at the International Gender and Sports Symposium, Ankara2014.

\section{References}

[1] Amano, M., Kanda, T. and Maritani, T. (2001) Exercise Training and Autonomic Nervous System Activity in Obese Individuals. Medicine \& Science in Sports \& Exercise, 33, 1287-1291. http://dx.doi.org/10.1097/00005768-200108000-00007 
[2] US Department of Health and Human Services (1987) Anthropometric Reference Data and Prevalence of Overweight. DHHS Publication, USA.

[3] Lew, E.A. and Garfinkel, L. (1979) Variations in Mortality by Weight among 750,000 Men and Women. Journal of Chronic Diseases, 32, 563-576. http://dx.doi.org/10.1016/0021-9681(79)90119-X

[4] Onat, A. (2007) Fiziksel Etkinlik, Metabolik Bozukluklardan Korunma ve Koroner Mortalite. Türk Halkının Kalp Sağlığı, Argos-Cortex, İstanbul.

[5] Segal, N.A., Hein, J. and Basford, J.R. (2004) The Effects of Pilates Training on Flexibility and Body Composition: An Observational Study. Archives of Physical Medicine and Rehabilitation, 85, 1977-1981. http://dx.doi.org/10.1016/j.apmr.2004.01.036

[6] Latey, P. (2001) The Pilates Method: History and Philosophy. Journal of Bodywork and Movement Therapies, 5, 275282. http://dx.doi.org/10.1054/jbmt.2001.0237

[7] Fox, E.L., Bowers, R.W. and Foss, M.L. (1989) The Physiological Basis of Physical Education and Athletics. William C Brown Publication, Philadelphia.

[8] Günay, M., Tamer, K. and Cicioğlu, İ. (2010) Spor Fizyolojisi ve Performans Ölçümü. Gazi Kitabevi, Ankara.

[9] Baysal, A. (2000) Genel Beslenme. Hatipoğlu Yayınları, Ankara.

[10] Ersoy, G.K. (1986) Spor ve beslenme. Mili Eğitim, Gençlik ve Spor Bakanlı̆̆ı Yayınları, Ankara.

[11] Ganong, W.F. and Barrett, K.E. (2005) Review of Medical Physiology. McGraw-Hill Medical Publication, New York.

[12] McArdle, W.B., Katch, F.I. and Katch, V.L. (2001) Exercise Physiology-Energy, Nutritionand Human Performance. Lippincott Williams and Wilkins, Philadelphia.

[13] Guyton, A.C. and Hall, J.E. (2006) Tıbbi Fizyoloji (Çev. Ed. Çavuşoğlu H.). Nobel TıpKitabevleri, İstanbul, $297-421$.

[14] Petra, M.L., Herbert, B.M. and Neuh, M. (2001) Effects of Fat Mass and Body Fat Distribution on Resting Metabolic Rate in the Elderly. Metabolism, 50, 972-975.

[15] Heyward, V. (1997) Advanced Fitness Assessment Exercise Prescription. Human Kinetics, Champaign.

[16] Bingham, S.A., Goldberg, G.R., Coward, W.A., Prentice, A.M. and Cummings, J.H. (1989) The Effect of Exercise and Improved Physical Fitness on Basal Metabolic Rate. British Journal of Nutrition, 61, 155-173. http://dx.doi.org/10.1079/BJN19890106

[17] Çolakoğlu, F.F. and ve Karacan, S. (2006) Genç Bayanlar ile Orta Yaş Bayanlarda Aerobik Egzersizin Bazı Fizyolojik Parametrelere Etkisi. Kastamonu Ĕgitim Dergisi, 14, 277-284.

[18] Lennon, D., Nagle, F., Stratman, F., Shrago, E. and Dennis, S. (1985) Diet and Exercise Training Effects on Resting Metabolic Rate. International Journal of Obesity, 9, 39-47.

[19] Lovlin, R., Cottle, W., Pyke, I., Kavanagh, M. and Belcastro, A.N. (1987) Are Indices of Free Radical Damage Related to Exercise Intensity. European Journal of Applied Physiology, 56, 313-316. http://dx.doi.org/10.1007/bf00690898

[20] Baumgartner, R.N., Cameron, C. and Roche, A.F. (1998) Bioelectrical Impedance for Body Composition. American Journal of Clinical Nutrition, 48, 16-25.

[21] Nieman, D.C., Trone, G.A. and Austin, M.D. (2003) A New Handheld Device for Measuring Resting Metabolic Rate and Oxygen Consumption. Journal of the American Dietetic Association, 103, 588-593. http://dx.doi.org/10.1053/jada.2003.50116

[22] World Health Organization (1995) Expert Committee on Physical Status: The Useand Interpretation of Anthropometry. WHO, Geneva.

[23] American College of Sports Medicine, Ed. (2013) ACSM’s Health-Related Physical Fitness Assessment Manual. Lippincott Williams \& Wilkins, Philadelphia.

[24] Fox, E.L., Bowers, R.W. and Foss, M.L. (1993) The Physiological Basis For Exercise and Sport. 5th Edition, Brown \& Benchmark, New York.

[25] Güllü, A. and Güllü, E. (2001) Genel Antrenman Bilgisi. Umut Matbaacılık, İstanbul.

[26] William, J.K., Monica, K., Nicholas, A.R., Jeff, S.V., Mathew, M., Jill, A.B., Bradley, C.N., Scoott, A.G., Scoott, A.M., Robert, U.N., Ana, L.G., Robbin, B.W., Martyn, R.R. and Keijo, H. (2001) Resistance Training Combined with Bench-Step Aerobics Enhances Woman's Health Profile. Medicine \& Science in Sports \& Exercise, 33, $259-269$.

[27] Fenkci, S., Sarsan, A., Rota, S. and Ardic, F. (2006) Effects of Resistance or Aerobic Exercises on Metabolic Parameters in Obese Women Who Are Not on a Diet. Advances in Therapy, 23, 404-413. http://dx.doi.org/10.1007/BF02850161

[28] Mensink, G.B., Ziese, T. and Kok, F.J. (1999) Benefits of Leisure-Time Physical Activity on the Cardiovascular Risk Profile at Older Age. International Journal of Epidemiology, 28, 659-666. http://dx.doi.org/10.1093/ije/28.4.659 
[29] Stasiulis, A., Mockiene, A., Vizbaraite, D. and Mockus, P. (2009) Aerobic Exercise-Induced Changes in Body Composition and Blood Lipids in Young Women. Medicina, 46, 129-134.

[30] Geliebter, A., Maher, M.M., Gerace, L., Gutin, B., Heymsfield, S.B. and Hashim, S.A. (1997) Effects of Strength or Aerobic Training on Body Composition, Resting Metabolic Rate and Peak Oxygen Consumption in Obese Dieting Subjects. The American Journal of Clinical Nutrition, 66, 557-563.

[31] Ballor, D.L. and Poehlman, E.T. (1992) Resting Metabolic Rate and Coronary-Heart-Disease Risk Factors in Aerobically and Resistance-Trained Women. The American Journal of Clinical Nutrition, 56, 968-974. http://dx.doi.org/10.1249/00005768-199205001-00303 